\title{
Pelatihan Membaca Puisi Bagi Siswa Madrasah Diniyah Ta'limul Huda Desa Randusanga Wetan
}

\author{
Robert Rizki Yono \\ Universitas Muhadi Setiabudi Brebes \\ email : Robertriskiyono@gmail.com
}

\begin{abstract}
Absence of teaching poetry in MDTA Ta'limul Huda in the village of Randusanga wetan. This has an impact on the knowledge that students have about the technique of reading less poetry. Ministry of religion held a Porsadin competition aims to explore and develop the potential of madrasah diniyah takmiliyah awaliyah in order to strengthen its existence in the community. Among them the art branch that is contested is reading Islamic poetry. So when following the Porsadin branches read the poems got unsatisfactory results. In fact, many benefits are derived from reading poetry. The activities of community dedication aims to provide training in reading poetry for the students in MDTA Ta'limul Huda in the village of Randusanga Wetan by implementing poetry reading techniques for students, so that the students of Randusanga Wetan is expected Knowing about poetry and being able to read poetry well. Method used is the method of presenting the material and the mentoring so as to get the results that are expected. Based on the implementation of the training activities read poetry for the students in MDTA Ta'limul Huda in the village of Randusanga Wetan that carried out well and smoothly can be concluded as follows. First, this activity generates new knowledge for students about poetry, especially poetry reading techniques. Secondly, participants gained various poetryreading techniques such as vocals, pauses, intonations, expressions, and passion.
\end{abstract}

Keywords: training activities, reading poetry, students.

\begin{abstract}
Abstrak
Tidak adanya pengajaran puisi di MDTA Ta'limul Huda Desa Randusanga Wetan. Hal ini berdampak pada pengetahuan yang dimiliki santri tentang teknik membaca puisi yang kurang. Kemenag mengadakan lomba porsadin bertujuan untuk menggali dan mengembangkan potensi Madrasah Diniyah Takmiliyah dalam rangka memperkokoh eksistensinya di masyarakat. Diantaranya cabang seni yang dilombakan yaitu membaca puisi islam. Sehingga saat mengikuti porsadin cabang membaca puisi mendapat hasil yang tidak memuaskan. Padahal, banyak manfaat yang didapatkan dari membaca puisi. Kegiatan pengabdian masyarakat ini bertujuan untuk memberikan pelatihan membaca puisi bagi santri MDTA Ta'limul Huda Desa Randusanga Wetan dengan mengimplementasikan teknik membaca puisi bagi santri, sehingga santri MDTA desa Randusanga Wetan diharapkan mengetahui tentang puisi dan mampu membaca puisi dengan baik. metode yang digunakan adalah metode penyajian materi dan pendampingan sehinga mendapatkan hasil yang sesuai dengan yang diharapkan. Berdasarkan pelaksanaan kegiatan pelatihan membaca puisi bagi santri MDTA Ta'limul Huda Desa Randusanga Wetan yang terlaksana dengan baik dan lancar dapat disimpulkan sebagai berikut. Pertama, kegiatan ini menghasilkan pengetahuan baru bagi santri tentang puisi, khususnya teknik membaca puisi. Kedua, peserta memperoleh teknik-teknik membaca puisi yang beragam seperti, vokal, jeda, intonasi, ekspresi, dan penghayatan.
\end{abstract}

Kata Kunci: kegiatan pelatihan, membaca puisi, santri.

Artikel diterima : 4 Ferbuari 2020 direvisi : 14 September 2020 disetujui : 1 Desember 2020 


\section{Pendahuluan}

Madrasah Diniyah Takmiliyah Awaliyah Ta'limul Huda Desa Randusanga Wetan adalah suatu lembaga pendidikan keagamaan Islam nonformal. Madrasah merupakan tempat belajar yang memberikan pengetahuan kepada para santri atau siswa tentang agama, akhlak yang mulia, dan pengembangan potensi dirinya. Madrasah berada dibawah naungan Kementerian Agama.

Kementerian Agama mengadakan pekan olahraga khusus santri yang disebut porsadin. Porsadin adalah pekan olahraga dan seni antardiniyah. Menurut Lukman (2017) dalam artikel yang berjudul FKDT gelar porsadin tingkat nasional ke III di Pasuruan Jawa Timur menyatakan bahwa porsadin bertujuan untuk menggali dan mengembangkan potensi Madrasah Diniyah Takmiliyah dalam rangka memperkokoh eksistensinya di masyarakat. Diantara cabang seni yang dilombakan yaitu membaca puisi Islam.

Hasil yang tidak memuaskan dari lomba membaca puisi didapatkan MDTA Ta'limul Huda Randusanga Wetan saat mengikuti porsadin tingkat Kabupaten tanggal 21 April 2019 di Ponpes Alhasaniyah desa Kedawon khususnya. Hal ini disebabkan oleh beberapa faktor. Pertama. Tidak adanya pembelajaran membaca puisi di Madrasah Desa Randusanga Wetan, sehingga potensi para santri tidak dioptimalkan atau dikembangkan. Kedua, pengajaran sastra di lembaga pendidikan nonformal (madrasah) tidak masuk dalam kurikulum. Hal ini selaras dengan UU No. 20 tahun 2003 tentang Sistem Pendidikan Nasional pada Bab VI jalur, jenjang, dan jenis pendidikan Bagian Kesatu Pasal 26 ayat 1 yang berbunyi pendidikan nonformal diselenggarakan bagi masyarakat yang memerlukan layanan pendidikan yang berfungsi sebagai pengganti, penambah, dan/atau pelengkap pendidikan formal dalam rangka mendukung pendidikan sepanjang hayat (Djahid, 2016).
Berdasarkan pasal 26 ayat 1 berarti pendidikan madrasah merupakan tambahan dan/atau pelengkap pendidikan formal. Padahal, kondisi pembelajaran sastra di lembaga pendidikan formal juga cukup memprihatinkan.

Salah satu jenis pengajaran sastra yaitu puisi. Puisi memiliki berbagai manfaat jika diapresiasikan, seperti membaca puisi. membaca puisi berbeda dengan membaca biasa. Membaca puisi si pembaca dituntut untuk dapat memuaskan pendengar. Karena membaca puisi bagian dari seni. Menurut Suharianto (dalam Tumingar, 2014) membaca puisi merupakan seni audiovisual, yang berarti bahwa seni baca puisi dituntut enak didengar dan enak dilihat. Agar enak didengar maka harus rajin berlatih mengenai pengucapan dan gerakan-gerakan yang mendukung keberhasilan dalam membaca puisi.

Sebagaimana pendapat Santosa (dalam Sari dkk, 2019) bahwa puisi memiliki lima manfaat, yaitu (1) keindahan, (2) pendidikan, (3) kepekaan batin dan sosial, (4) menambah wawasan, dan (5) pengembangan kejiwaan atau kepribadian). Lebih lanjut, menurut Suharianto (dalam Mulyono, 2010) menyatakan bahwa pembelajaran membaca puisi akan memberikan dua hal pokok pengetahuan kepada siswa yaitu penghayatan dan teknik vokal/pelafalan.

Penghayatan merupakan faktor terpenting dalam keberhasilan membaca puisi yang berkaitan dengan intonasi, jeda, irama, gerak tubuh, dan mimik. Pelafalan atau pengucapan bunyi-bunyi bahasa, baik bunyi hidup atau pun bunyi mati. Selain itu, Dengan demikian berarti bahwa pembelajaran puisi bagi santri atau siswa madrasah sangat diperlukan karena begitu banyak manfaat yang kelak didapat para santri dan santri juga dapat mempersiapkan diri dengan baik untuk mengikuti porsadin.

Keadaan santri saat ini dalam tahap perkembangan, baik fisik maupun mental. Lingkungan keluarga dan madrasah wajib membimbing perkembangan santri ke arah yang positif agar kelak mereka menjadi 
manusia yang baik dan benar. Salah satu sarana untuk mencapai tujuan tersebut adalah mengenalkan puisi yang sesuai dengan tahap perkembangan siswa yaitu puisi islami.

Berdasarkan latar belakang di atas, masalah yang dihadapi santri adalah tidak ada pengajaran puisi di madrasah. Hal ini berdampak pada pengetahuan yang dimiliki santri tentang teknik membaca puisi sangat kurang, membaca puisi seperti membaca biasa. Sehingga saat mengikuti porsadin cabang membaca puisi mendapat hasil yang tidak memuaskan. Prioritas masalah yang dapat diatasi melalui kegiatan pengabdian pada masyarakat yang berupa pelatihan ini mencakup:

1) Kurangnya pengetahuan santri tentang puisi;

2) Santri tidak mengetahui teknik membaca puisi yang baik.

Pengabdian masyarakat ini bertujuan untuk memberikan pelatihan membaca puisi bagi santri MDTA Ta'limul Huda Desa Randusanga Wetan dengan mengimplementasikan teknik membaca puisi bagi santri, sehingga santri MDTA desa Randusanga Wetan diharapkan mengetahui tentang puisi dan mampu membaca puisi dengan baik. Adapun iptek dalam kegiatan pengabdian ini yaitu melakukan pelatihan membaca puisi dan memanfaatkan media power point serta model pembelajaran ATM (amati, tiru, dan modifikasi).

\section{Pelaksanaan dan Metode}

Adapun metode pelaksanaan yang akan dilakukan sebagai berikut.

1. Pemberian materi pengertian puisi, unsur-unsur puisi, jenis-jenis puisi, dan teknik membaca puisi.

Pelatihan ini menggunakan media power point, metode tanya jawab dan demontrasi, serta model pembelajaran ATM (amati, tiru, dan modifikasi). Melalui penyajian materi dan praktik. Dipilihnya model ATM dalam pembelajaran membaca puisi menurut Tuminggar (2014) karena model ATM terbukti dapat meningkatkan hasil belajar membaca puisi. Pelatihan ini bertujuan memberikan pengetahuan tentang materi pengertian puisi, unsurunsur puisi, jenis-jenis puisi, dan teknik membaca puisi kepada santri MDTA Ta'limul Huda desa Randusanga Wetan. Peserta yang ditargetkan menjadi sasaran dalam kegiatan ini 50 santri (kelas 3 dan 4). Dosen pelaksana bertindak sebagai narasumber. Target yang diharapkan pada pertemuan pertama, yaitu meningkatkan pengetahuan siswa tentang baca puisi dan mengembangkan potensi santri dalam membaca puisi.

2. Kegiatan membaca puisi.

Kegiatan membaca puisi bertujuan memberikan pengetahuan dan bimbingan kepada santri agar mampu membaca puisi dengan baik. pengabdi melakukan pendampingan kepada santri dalam kegiatan praktik membaca puisi. Kegiatan membaca puisi ditargetkan agar setiap santri mampu membaca puisi dengan memperhatikan lafal, intonasi, nada, ekspresi, dan penghayatan yang baik sesuai dengan puisi islami yang dibacanya. Pemberian materi dilakukan di dalam kelas dan praktik dilakukan diluar kelas.

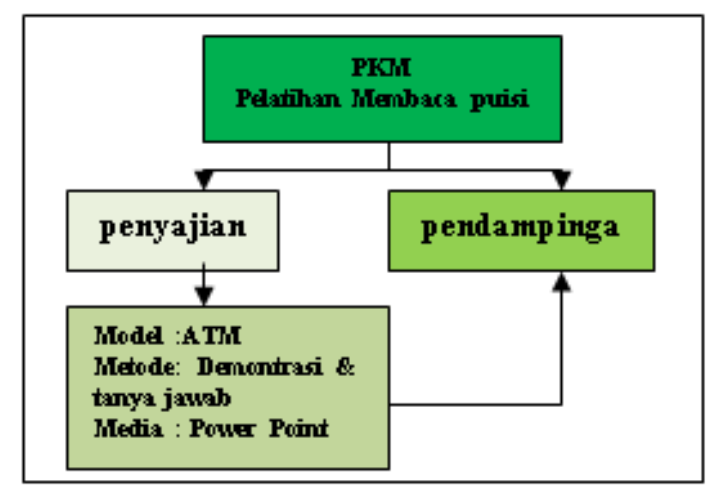

Gambar 1. Desain Pelaksanaan Pelatihan

3. Pelaksanaan kegiatan

Realisasi pelaksanaan pelatihan membaca puisi bagi santri MDTA Ta'limul Huda Desa Randusanga Wetan dilakukan dari bulan Juli-Agustus 2019. Tahap persiapan sebelum kegiatan PKM dimulai yaitu pembukaan dan kontrak belajar pelatihan. Pembukaan dilakukan oleh ustad dengan tujuan menginformasikan bahwa 
akan dilaksanakannya pelatihan membaca puisi. Dilanjutkan dengan menggali pengetahuan awal peserta tentang puisi sebelum kegiatan pelatihan dimulai. Kontrak belajar pelatihan ini digunakan agar proses kegiatan pelatihan tertib dan lancar. Tahapan yang dilakukan dalam pelaksanaan PKM sebagai berikut. .

Pertama, penyajian materi diawali dengan memberikan materi tentang puisi khususnya cara membaca puisi dengan menggunakan metode demontrasi dan media power point. Materi yang disampaikan seperti definisi, unsur, jenis, dan teknik membaca puisi. Setelah materi terselesaikan dilanjutkan dengan tanya jawab sesuai pokok bahasan. Selanjutnya menerapkan metode demontrasi dan model ATM dengan menggunakan media video untuk memberikan contoh membaca puisi islami. Model ATM diterapkan dengan tujuan agar santri dapat mengamati, meniru, dan mampu memodifikasi ciri khas dari contoh pembacaan yang telah ditampilkan dilanjutkan dengan praktik. Setelah mendapatkan pengetahuan tentang puisi dilanjutkan dengan latihan membaca puisi yang dipraktikan oleh santri satu persatu di halaman Madrasah dengan tujuan menambah rasa percaya diri santri dan melatih mental santri.

Kedua, kegiatan pendampingan dilakukan agar santri dapat memperbaiki hasil dari pembacaan puisi seperti kesulitan yang dialami santri mengenai pembacaan puisi. Pendampingan dilakukan sampai akhir proses pelatihan membaca puisi sesuai yang diharapkan dalam tujuan pengabdian kepada masyarakat ini, agar dapat mengoptimalkan potensi yang dimiliki santri MDTA Ta'limul Huda Desa Randusanga Wetan. Setelah semua tahapan selesai, diakhiri dengan evaluasi akhir kegiatan.

\section{Hasil dan Pembahasan}

Pelaksanaan kegiatan pengabdian masyarakat ini dilakukan pada tanggal 15
Juli-15 Agustus 2019 dengan dua kegiatan yaitu:

1. Penyajian materi puisi

a. Tahapan persiapan

Tahapan ini dilakukan pada awal bulan Juli 2019. Pengabdi melakukan diskusi dengan kepala madrasah dan beberapa ustad terkait tentang rencana pelaksanaan kegiatan pelatihan membaca puisi ini. Hasil diskusi ini mencakup beberapa hal sebagai berikut.

Persiapan waktu dan tempat kegiatan.

1). Kegiatan sosialisasi terkait pelatihan membaca puisi kepada ustad madrasah dan Robert Rizki Yono, M. Pd. merupakan seorang pelaksana kegiatan pengabdian yang sesuai dengan bidang keahlinnya yang akan dilaksanakan di MDTA Ta'limul Huda Desa Randusanga Wetan pada tanggal Juli 2019.

2). Kegiatan pelatihan membaca puisi oleh pengabdi kepada santri MDTA Ta'limul Huda Randusanga Wetan di laksanakan pada tanggal 20 Juli 2019.

Pembukaan

1). Pembukaan dilakukan oleh ustad dengan tujuan menginformasikan akan dilaksanakannya pelatihan membaca puisi. Dilanjutkan oleh pengabdi, menyampaikan ucapan salam, menciptakan kondisi kelas, memperkenalkan diri dan berusaha mengenal santri, menjelaskan tujuan kegiatan pengabdian masyarakat, menjelaskan manfaat pokok bahasan, menggali pengalaman belajar dan pengetahuan yang berkaitan dengan judul pengabdian, menyiapkan sarana yang diperlukan.

2). Kontrak belajar pelatihan digunakan dalam pelatihan ini agar kegiatan pelatihan berjalan tertib. 


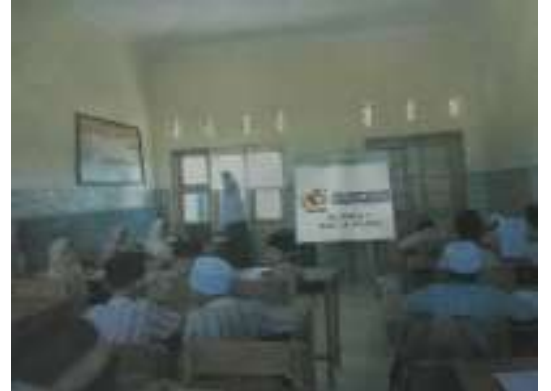

Gambar 2. Pemaparan Kotrak Belajar

Penyajian Materi

1). Pelatihan membaca puisi diawali dengan memberikan materi tentang gambaran umum puisi dan khususnya teknik membaca puisi dengan menggunakan metode demontrasi dan media power point. Materi yang disampaikan yaitu definisi, unsur, jenis, dan teknik membaca puisi. Setelah materi selesai dilanjutkan dengan tanya jawab sesuai dengan pokok bahasan.

2). Dilanjutkan dengan mengunakan metode demontrasi dan model ATM (amati, tiru, dan modifikasi) dengan memanfaatkan media video untuk memberikan contoh pembacaan puisi islami. Model ATM bertujuan agar santri dapat mengamati, meniru dan mampu memodifikasi contoh pembacaan yang telah ditampilkan dan santri satu persatu mengamati pembacaan puisi di video tersebut, meniru pembacaan puisi di video tersebut, dan masing-masing santri memodifikasi cara membaca berdasarkan pembacaan puisi yang ada di video tersebut.

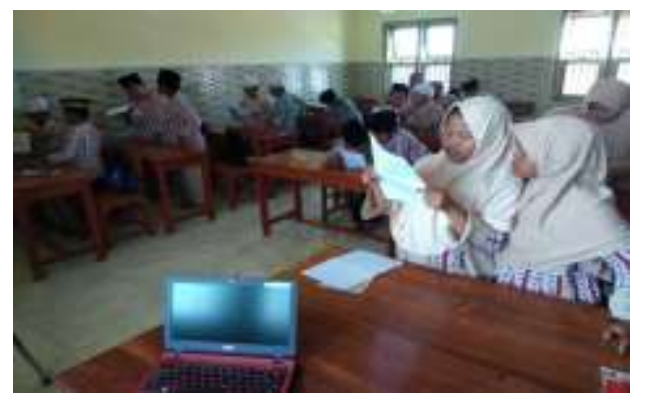

Gambar 3. Santri sedang menirukan pembacaan puisi berdasarkan video yang telah ditonton
Praktik

Setelah santri mendapatkan pengetahuan tentang puisi dilanjutkan dengan praktik membaca puisi satu per satu di halaman madrasah dengan tujuan untuk menambah rasa percaya diri santri dan agar memperoleh suasana belajar yang baru.

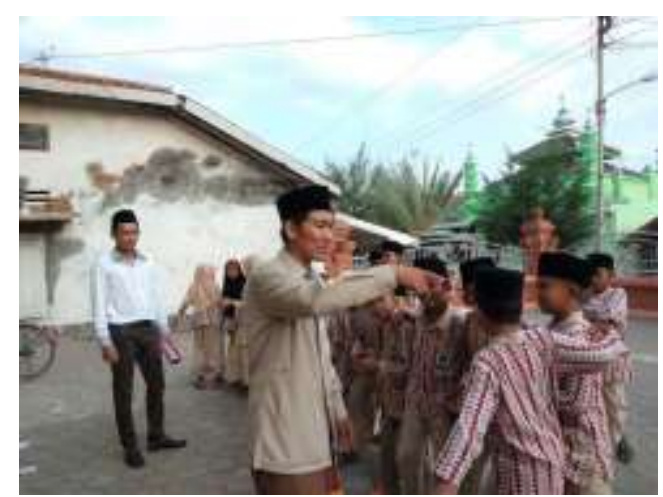

Gambar 4. Peserta pelatihan sangat antusias

\section{Pendampingan}

Pendampingan dilakukan sampai dengan akhir proses pelatihan membaca puisi sesuai dengan harapan dalam tujuan pengabdian masyarakat ini, agar dapat mengoptimalkan potensi yang dimiliki santri MDTA Ta'limul Huda Desa Randusanga Wetan.

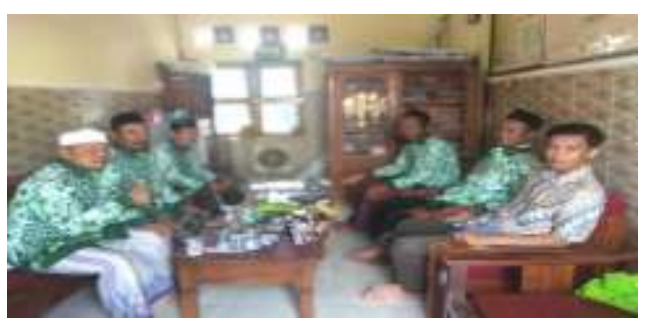

Gambar 5. Tahap pendampingan

Penutup

Setalah seluruh kegiatan dilaksanakan, maka diakhiri dengan evaluasi akhir pada pembacaan puisi oleh santri.

Tahapan Evaluasi

Kegiatan ini berjalan dengan lancar. Kegiatan ini juga menghasilkan pengetahuan baru bagi peserta tentang puisi, khususnya teknik membaca puisi. Teknik yang diperolehpun beragam, seperti teknik vokal, jeda, intonasi, ekspresi, dan penghayatan. Peserta sangat antusias mengikuti 
kegiatan pelatihan ini. Hal ini dibuktikan dengan santri mengamati, meniru, dan termotivasi untuk memodifikasi teknik membaca puisi sesuai dengan puisi yang ditontonnya. Tahapan berikutnya yaitu pendampingan, santri berusaha mempraktikkan teknik pembacaan puisi sesuai dengan puisi islami yang dibacanya. Secara umum, peserta menunjukan hasil yang cukup baik. hal ini akan membantu santri, baik dari sisi pengetahuan dan pengoptimalan potensi maupun saat adanya event lomba baca puisi saat porsadin.

Ansari, Asri, dan Nurhusna (2018) bahwa ketercapaian tujuan pelaksanaan pelatihan membaca puisi ditunjukan melalui indikator keberhasilan dalam penilaian selama kegiatan pelatihan berlangsung. Sebagaimana santri MDTA Ta'limul Huda Desa Randusanga Wetan mampu mengidentifikasi masalah dalam membaca puisi dan membaca puisi dengan memperhatikan vokal, jeda, intonasi, ekspresi dan penghayatan.

\section{Kutipan dan Acuan}

Beberapa penelitian yang berkaitan dengan pelatihan membaca puisi bagi peserta didik diantaranya yaitu, Penelitian Anshari, Asri, dan Nurhusna (2018) menggunakan 4 teknik dalam membaca puisi yang meliputi, interpretasi, vokal, pernafasan dan penampilan. Menurut hasil penelitian Tuminggar (2014) mengimplementasikan model pembelajaran Amati, tiru, dan modifikasi dalam membaca puisi dapat terbukti dapat meningkatkan hasil belajar membaca puisi dan siswa lebih antusias dala proses pembelajaran membaca puisi.

Gusneli (2017) dalam penelitiannya menggunakan metode demontrasi dapat meningkatkan kemampuan siswa dalam membaca puisi. Sari, Chamisijatin, dan Santoso (2019) dalam penelitiannya mengatakan bahwa penerapan model demontrasi dan media video dapat meningkatkan keterampilan membaca puisi. Hanif, Fathurohman, dan Sumarwiyah (2018) menghasilkan penelitian yang mampu meningkatkan keterampilan membaca puisi pada siswa kelas V SD 1 Tritis Jepara dengan menggunakan model CIRC dan memanfaatkan media video pembacaan puisi.

Oleh karena itu, hasil penelitian sebelumnya dapat diimplementasikan karena menjadi solusi dalam mengatasi masalah cara membaca puisi bagi siswa atau santri MDTA Ta'limul Huda Desa Randusanga Wetan dengan memberikan pelatihan membaca puisi dengan memanfaatkan berbagai metode, media, dan model pembelajaran ATM. Luaran dalam kegiatan ini yaitu santri mengetahui gambaran umum puisi dan menerapkan teknik membaca puisi dengan baik.

\section{Penutup}

\section{Simpulan}

Berdasarkan pelaksanaan kegiatan pelatihan membaca puisi bagi siswa atau santri MDTA Ta'limul Huda Desa Randusanga Wetan yang terlaksana dengan baik dan lancar dapat disimpulkan sebagai berikut. Pertama, kegiatan ini menghasilkan pengetahuan baru bagi santri tentang puisi, khususnya teknik membaca puisi. Kedua, peserta memperoleh teknik-teknik membaca puisi yang beragam seperti, vokal, jeda, intonasi, ekspresi, dan penghayatan.

\section{Saran}

Pelatihan membaca puisi bagi siswa Madrasah Diniyah Takmiliyah Awaliyah sangat penting pada kemajuan Pendidikan Bahasa dan Sastra serta perkembangan siswa. Tekait pelatihan membaca puisi ini maka ada saran untuk pembaca dan tenaga pengabdian kepada masyarakat yaitu Pelatihan membaca puisi bagi siswa Madrasah Diniyah Takmiliyah Awaliyah Ta'limul Huda Al-Hasyimiyyah Randusanga Wetan masih perlu dilakukan, terutama masalah penghayatan dan diharapkan pengajaran sastra masuk dalam kurikulum MDTA atau para ustad mengajarkan puisi setiap hari Kamis Pon karena sangat 
banyak manfaatnya untuk santri serta karena Kementerian Agama selalu mengadakan lomba baca puisi dalam Porsadin.

\section{Ucapan terima kasih}

Terima kasih saya sampaikan kepada seluruh jajaran MDTA Ta'limul Huda Desa Randusanga Wetan, UMUS Brebes, jurnal Cendekia dan pihak yang terlibat dalam kegiatan pengabdian masyarakat ini.

\section{Daftar Pustaka}

Anshari, aswati, dan Nurhusna. Pelatihan cipta dan baca puisi bagi siswa SPM di Kabupaten Gowa. Prosiding seminar nasional hasil pengabdian kepada masyarakat. 2018. No. 9 http://ojs.unm.ac.id/semnaslpm/arti cle/view/8087

Djahid. 2016. Penyelengaraan Pendidikan Madrasah Diniyah Takmiliyah di Ponorogo. Jurnal Muaddib. No. 6. Vo. $1 . \quad$ Available: http://journal.umpo.ac.id/index.php /muaddib/article/view/164

Gusneli. 2017. Upaya meningkatkan kemampuan membaca puisi dengan metode demonstrasi siswa kelas XII MIA 3 SMAN 1 Pekanbaru. Jurnal PAJAR. Vol. 1, No. 2. Available from:

https://media.neliti.com/media/publ ications/258158-upaya meningkatkan-kemampuan membaca-pui-ecac67c0.pdf

Hanif, Fathurohman, dan Sumarwiyah. 2018. Peningkatan keterampilan membaca puisi dengan eksperimentasi model CIRC bermedia video pembacaan puisi pada siswa kelas V SD 1 Tritis Jepara. Jurnal Kredo. Vo. 2. No. 2. Available:

https://jurnal.umk.ac.id/index.php/k redo/article/download/2784/1476.

Maryani.2017. FKDT Gelar Porsadin Tingkat Nasional ke III di Pasuruan JawaTimur.Available: http://www.pendis.kemenag.go.id/i ndex.php?a=detil\&id=9197

Mulyono, Tri 2010. Diklamasi dan baca puisi. Tegal: UPS

Tuminggar, sriwahyuni. 2014. Peningkatan keterampilan membaca puisi dengan model amati, tiru, dan modifikasi menggunakan media video pembacaan puisi pada siswa kelas VII SMPN I Sambong Kabupaten Blora. Skripsi. PBSI, FBS, UNNES, Semarang. Available:

http://www.Google.com/url?sa=t\& source $=$ web\&rct=j\&url=http://lib.u nnes.ac.id/21218/1/2101409017s.pdf\&ved

Sari, Chamisijatin, dan Santoso. 2019. Peningkatan keterampilan membaca puisi bagi siswa kelas IV dengan model demontrasi didukung media video pembelajaran di SDN 1 Sumbersari Kota Malang. Refleksi Edukatika. Jurnal Ilmiah Kependidikan. Vol. 9. No. 2. Available from: http://jurnal.umk.ac.id/index.php/R E 